\title{
Investigation of Mycoplasma spp. in birds of the Rio de Janeiro Zoo by isolation and PCR ${ }^{1}$
}

\author{
Bárbara S.N. Magalhães ${ }^{2 *}$ (D), Virginia Léo A. Pereira ${ }^{3}$, Thomas S. Dias ${ }^{3}$ (D), \\ Leandro S. Machado ${ }^{3}$ (D) Mariane M. Silva ${ }^{3}$, Elmiro R. Nascimento ${ }^{3}$, \\ Flavya Mendes-de-Almeida ${ }^{2}$ and Nádia Regina P. Almosny ${ }^{2}$
}

\begin{abstract}
Magalhães B.S.N., Pereira V.L.A., Dias T.S., Machado L.S., Silva M.M., Nascimento E.R., Mendes-de-Almeida F. \& Almosny N.R.P. 2020. Investigation of Mycoplasma spp. in birds of the Rio de Janeiro Zoo by isolation and PCR. Pesquisa Veterinária Brasileira 40(3):210-215. Faculdade de Veterinária, Universidade Federal Fluminense, Rua Vital Brazil Filho 64, Niterói, RJ 24230-340, Brazil. E-mail: barbaraneil@hotmail.com

Brazil is one of the countries with the most abundant avifauna in the world. The confinement of birds associated with close contact with other animals and humans favor the spread of agents of respiratory diseases. Among them, mycoplasmas can cause asymptomatic or apparent disease that manifests in birds by coughing, sneezing, rales, conjunctivitis, ocular and nasal discharge. Several described mycoplasmas cause disease in birds, especially Mycoplasma gallisepticum (MG) and Mycoplasma synoviae (MS). The diagnosis of Mycoplasma spp. can be done by clinical observation and laboratory analysis. Molecular diagnosis by PCR was boosted by its speed, sensitivity, and low cost of agent isolation techniques that take up to 21 days to complete. This study aimed to verify the occurrence of Mycoplasma spp. in birds of the Rio de Janeiro Zoo (Rio Zoo), by isolation and PCR. Of the total 635 birds from the Rio Zoo, 81 were studied for detection of Mycoplasma spp., when taken for routine health assessment exams. These birds belonged to the following orders: Psittaciformes (45), Accipitriformes (18), Galliformes (7), Piciformes (5), Strigiformes (4), Falconiformes (1) and Cariamiformes (1), all individuals already identified by microchip or leg-ring. There was no isolation of mycoplasmas in any of the samples tested, whereas, in the PCR, 62.96\% (51/81) were positive, with $1.96 \%$ (1/51) identified as MG and 19.61\% (10/51) as MS, representing $1.23 \%(1 / 81)$ and $12.34 \%$ (10/81) of the total population studied. PCR was shown to be a more effective technique than isolation in the detection of Mycoplasma spp. in birds. It was possible to detect mycoplasmas in birds from Riozoo with no clinical respiratory signs, with higher MS prevalence than MG. The positivities for Mycoplasma spp., MS, and MG were different among the orders studied, being the highest occurrence in birds of prey, followed by Galliformes and Piciformes. The presence of MG and MS in birds of Rio de Janeiro Zoo confirms the circulation of these agents and the need for further studies on the dissemination of mycoplasmas in zoos for the epidemiological analysis of these bacteria in these places.
\end{abstract}

INDEX TERMS: Investigation, Mycoplasma spp., birds, Rio de Janeiro, Brazil, zoo, captive.

\footnotetext{
${ }^{1}$ Received on August 13, 2019.

Accepted for publication on September 10, 2019.

${ }^{2}$ Graduate Program in Veterinary Medicine, Clinics and Animal Reproduction, Faculdade de Veterinária, Universidade Federal Fluminense (UFF), Rua Vital Brazil Filho 64, Niterói, RJ 24230-340, Brazil.

${ }^{3}$ Departamento de Saúde Coletiva Veterinária e Saúde Pública, Universidade Federal Fluminense (UFF), Rua Vital Brazil Filho 64, Niterói, RJ 24230-340. *Corresponding author: barbaraneil@hotmail.com
}

RESUMO.- [Investigação de Mycoplasma spp. em aves do Zoológico do Rio de Janeiro por isolamento e PCR.] O Brasil é um dos países com maior avifauna do mundo. 0 confinamento de aves associado ao contato próximo a outros animais e seres humanos favorece a disseminação de agentes etiológicos causadores de doenças respiratórias. Dentre eles, os micoplasmas podem causar doença assintomática ou aparente que se manifesta em aves por espirros, estertores, 
conjuntivite, corrimentos oculares e nasais. São diversos os micoplasmas descritos causadores de doença em aves, com destaque para Mycoplasma gallisepticum (MG) e Mycoplasma synoviae (MS). 0 diagnóstico de Mycoplasma spp. pode ser feito pela observação clínica e análises laboratoriais. 0 diagnóstico molecular pela Reação em Cadeia da Polimerase (PCR) ganhou impulso por sua rapidez, sensibilidade e baixo custo em relação às técnicas de isolamento do agente que levam até 21 dias para conclusão do gênero Mycoplasma. Objetivou-se verificar a ocorrência da infecção por Mycoplasma spp. em aves no Zoológico do Rio de Janeiro (Rio Zoo), por isolamento e PCR. Do plantel de 635 aves do Rio Zoo, foram estudadas 81 para detecção de Mycoplasma spp., quando contidas para exames rotineiros de avaliação da condição de saúde. Essas aves eram pertencentes às ordens Psittaciformes (45), Accipitriformes (18), Galliformes (7), Piciformes (5), Strigiformes (4), Falconiformes (1) e Cariamiformes (1), todas já identificadas por microchip ou por anilha. Não houve isolamento de micoplasmas em nenhuma das amostras testadas, enquanto na PCR, 62,96\% (51/81) foram positivas, sendo 1,96\% (1/51) identificadas como MG e 19,61\% (10/51) como MS, representando 1,23\% (1/81) e 12,34\% (10/81) da população total estudada. A PCR demonstrou ser uma técnica mais efetiva que o isolamento na detecção de Mycoplasma spp. em aves. Foi possível detectar micoplasmas nas aves do Riozoo sem sinal clínico respiratório, tendo MS maior prevalência do que MG. As positividades para Mycoplasma spp., MG e MS foram diferentes entre as ordens de aves estudadas, sendo a maior ocorrência nas aves de rapina, seguida dos Galliformes e dos Piciformes. A presença de MG e MS nas aves do Rio de Janeiro Zoo confirma a circulação destes agentes e a necessidade de mais estudos sobre a disseminação de micoplasmas em zoológicos para análise epidemiológica dessas bactérias nesse local.

TERMOS DE INDEXAÇÃO: Investigação, Mycoplasma spp., aves, zoológico, Rio de Janeiro, Brasil, PCR, cativeiro.

\section{INTRODUCTION}

The birds are the most studied and valued group of animals in the world with more than 11,000 different species and an extraordinary variety. Some occur in abundance, and others represented by a few remaining individuals. It is estimated that in Brazil, there are from 1600 to 1900 bird species, more than $10 \%$ of them endemic, which makes it to be considered one of the most avifauna countries in the world (Lewinsohn \& Prado 2005). To present these different bird species to the public, zoos around the world have facilities for the maintenance of these captive animals. However, the confinement of animals, associated with their contact with visitors and breeders, make the transmission and dissemination of pathogens a specific risk in these places (Cubas 2008, Loria et al. 2008). Among these agents are those that cause respiratory diseases, with emphasis on mycoplasmas that can cause apparent or subclinical disease in birds (Nascimento \& Pereira 2009). Its spread occurs directly or indirectly horizontally through people, other animals, feed, water, and fomites. In addition to this pathway, vertical transmission via egg or venereal may occur through mating or artificial insemination (Stipkovits \& Kempft 1996, Nascimento \& Pereira 2009).

Clinical signs commonly seen in wild and captive birds are sneezing, rales, eye and nasal discharge, unilateral conjunctivitis, or bilateral or not accompanied by enlargement of the infraorbital sinus and may be associated with chronic infections (Phalen et al. 2006). Among the main species of the genus Mycoplasma, stand out M. gallisepticum (MG) and $M$. synoviae (MS) which, cause an apparent or asymptomatic respiratory condition. But other species such as M. gypis, M. vulturii, M. gallinarum, M. gallinaceum, $M$. iners and $M$. corogypsi have been described as causing disease in birds (Poveda et al. 1990, Panangala et al. 1993, Fischer et al. 1997, Oaks et al. 2004).

To reduce the risk of these infections in bird populations and to assess the sanitary control of poultry, it is crucial to know and monitor these mycoplasmas in the environment by epidemiological surveys and laboratory tests associated with the development and implementation of strict standards and procedures in livestock (Vilani 2006). The mycoplasmic diagnosis can be presumptive with clinical and epidemiological, anatomopathological, serological, and etiological evaluations by agent isolation or PCR (Nascimento et al. 2005, Umar et al. 2017). Because these microorganisms are tedious, requiring enriched culture media, and they are slow to grow exponentially, bacteriological isolation has been used in conjunction with molecular techniques. PCR is fast, sensitive, requires a low laboratory cost, and does not allow the need for isolation from clinical specimens (Islam et al. 2011). Therefore, the objective was to verify the occurrence of Mycoplasma spp. in birds of different orders at the "Zoológico do Rio de Janeiro" (Rio Zoo) by isolation and PCR.

\section{MATERIALS AND METHODS}

The project was submitted and approved under no. 1017 by "Comissão de Ética no Uso de Animais" (CEUA) of "Universidade Federal Fluminense" and by "Sistema de Autorização e Informação em Biodiversidade" (SISBIO-ICMBio) under number 59538-1. In addition, the project was registered in "Sistema Nacional de Gestão do Patrimônio Genético e do Conhecimento Tradicional Associado" (SISGEN), no. A4E34FC.

Material collection. From the 635 birds of Rio Zoo, 81 were studied, belonging to the order Psittaciformes (45), Accipitriformes (18), Galliformes (7), Piciformes (5), Strigiformes (4), Falconiformes (1) and Cariamiformes (1) (Table 1), all already identified by microchip or washer. The animals were manually restrained for routine health assessment and samples collected of swab tracheal, which were conditioned in microtubes containing modified Frey's liquid medium (Nascimento 2000). The microtubes containing the swabs were kept refrigerated until the time of laboratory processing.

Isolation of Mycoplasma spp. An aliquot of $0.2 \mathrm{~mL}$ of the collected sample was inoculated into $1.8 \mathrm{~mL}$ of the modified Frey liquid medium. Serial dilutions were made until $10^{-5}$, and the dilutions $10^{-3}$ and $10^{-5}$ were seeded on plates containing modified Frey solid medium (Nascimento 2000). All samples were incubated at $37^{\circ} \mathrm{C}$ under microaerophilic and observed for 21 days under a 100x magnification stereoscopic microscope (Razin et al. 1998).

DNA extraction. A $500 \mu \mathrm{l}$ aliquot of the collected sample was submitted to DNA extraction by the phenol-chloroform adapted method (Sambrook \& Russell 2006). Each sample was then homogenized and centrifuged at $13,500 \mathrm{rpm}$ at $10^{\circ} \mathrm{C}$ for 20 minutes. After centrifugation, the supernatant was discarded, and $400 \mu \mathrm{L}$ of Tris Ethylenediaminetetraacetic acid (TE) dextrose, $30 \mu \mathrm{l} 10 \%$ sodium dodecyl sulfate (SDS) and $30 \mu \mathrm{l}$ proteinase $\mathrm{K} 240 \mu \mathrm{g} / \mu \mathrm{l}$ were added to the pellet. The sample was taken to the thermal block at $50^{\circ} \mathrm{C}$ for 
30 minutes with a subsequent ice bath for 5 minutes. Subsequently, $500 \mu \mathrm{L}$ of phenol was added to the samples, homogenized by inversion for 15 minutes, and then centrifuged at 13,500 rpm at $10^{\circ} \mathrm{C}$ for 30 minutes. The supernatant was removed and added to a new microtube with the same volume of chloroform, followed by gentle homogenization for 3 minutes and centrifugation under the conditions already described. The supernatant was removed, added to a $1 \mathrm{ml}$ microtube of ethyl alcohol, and precipitated "overnight." The precipitated DNA was centrifuged at $13500 \mathrm{rpm}$ at $10^{\circ} \mathrm{C}$ for 20 minutes and the pellet after drying; it was resuspended in $100 \mu \mathrm{L}$

Table 1. Order, species, common name and number of birds of the Rio de Janeiro Zoo evaluated for the detection of Mycoplasma spp.

\begin{tabular}{|c|c|c|c|c|}
\hline Order & Species & Common name & Number & Total \\
\hline \multirow[t]{7}{*}{ Psittaciformes } & Amazona aestiva & Real parrot & 9 & \multirow{7}{*}{45} \\
\hline & Amazona ocrocephala & Puffin parrot & 1 & \\
\hline & Ara macao & Scarlet macaw & 3 & \\
\hline & Ara chloropterus & Red macaw & 3 & \\
\hline & Guaruba guarouba & Ararajuba & 10 & \\
\hline & Pyrrhura frontalis & Red-fronted tiriba & 1 & \\
\hline & Pionus maximilliani & Green parrot & 3 & \\
\hline \multirow[t]{2}{*}{ Accipitriformes } & Amadonastur lacernulatus & Pigeon hawk & 3 & \multirow{2}{*}{18} \\
\hline & Rupornis magnirostris & Carijó hawk & 4 & \\
\hline Falconiformes & Milvago chimachima & Yellow-tailed hawk & 1 & 1 \\
\hline \multirow[t]{5}{*}{ Galliformes } & Pavo muticus & Peacock & 2 & \multirow{5}{*}{7} \\
\hline & Crax alector & Black porcupine & 2 & \\
\hline & Crax fasciolata & Pinum curassow & 1 & \\
\hline & Chrylophus pictus & Canary pheasant & 1 & \\
\hline & Pavo cristatus & Blue peacock & 1 & \\
\hline
\end{tabular}

Table 2. Primer oligonucleotides for PCR for detection of avian Mycoplasma with their sequences, amplified product size, and reference

\begin{tabular}{|c|c|c|c|}
\hline "Primers" & Sequence & Product & Reference \\
\hline Mspp GPO3 & 5'GGGAGCAAACAGGATTAGATACCCT3' & \multirow{2}{*}{$270 \mathrm{pb}$} & \multirow{2}{*}{ Van Kuppeveld et al. $(1992,1993)$} \\
\hline Mspp MGSO & 5'TGCACCATCTGTCACTCTGTTAACCTC3' & & \\
\hline MG-f & 5’CGTGGATATCTTTAGTTCCAGCTGC3' & \multirow{2}{*}{$481 \mathrm{pb}$} & \multirow{2}{*}{ Nascimento et al. (2005) } \\
\hline MG-r & 5'GTAGCAAGTTATAATTTCCAGGCAT3' & & \\
\hline MS-f & 5’GAGAAGCAAAATAGTGATATCA3' & \multirow{2}{*}{$207 \mathrm{pb}$} & \multirow{2}{*}{ Lauerman etal. (1993) } \\
\hline MS-r & 5'CAGTCGTCTCCGAAGTTAACAA3' & & \\
\hline
\end{tabular}

Mspp f and Mspp r = Mycoplasma spp., MG-f and MG $-\mathrm{r}=$ Mycoplasma gallisepticum, MS $-\mathrm{f}$ and MS-r = Mycoplasma synoviae. 
of TE buffer, quantified in Biodrop Touch ${ }^{\circledR}$ (Biochrom) and stored at $-20^{\circ} \mathrm{C}$ until PCR.

PCR. The extracted DNA was submitted to PCR for the detection of Mycoplasma spp., Mycoplasma gallisepticum (MG), and Mycoplasma synoviae (MS) respectively, according to Van Kuppeveld et al. (1992, 1993), Nascimento et al. (2005) and Lauerman et al. (1993). The PCR for detection of Mycoplasma spp. was performed in $25 \mu$ final volume containing $2 \mu \mathrm{l}$ isolated DNA, $1 \times$ PCR buffer $(10 \mathrm{mM}$ Tris$\mathrm{HCl}, \mathrm{pH} 8.0$ and $50 \mathrm{mM}$ of $\mathrm{KCl}$ ), $2 \mathrm{mM} \mathrm{MgCl} 2,0.2 \mathrm{mM}$ deoxynucleotide triphosphate (dNTP), $0.2 \mathrm{mM}$ forward and reverse primers and $1 \mathrm{U}$ Taq polymerase. For MG detection the reaction contained: 1X PCR buffer; $2 \mathrm{mM} \mathrm{MgCl2}$; $0.2 \mathrm{mM}$ dNTP; $0.2 \mathrm{nmol}$ of each specific primer (Table 2); $1 \mathrm{U}$ Taq Polymerase (Ludwig, Brazil) and extracted DNA totaling $25 \mu \mathrm{l}$. The MG PCR was performed under the following conditions: $95^{\circ} \mathrm{C}$ for 5 minutes, followed by 40 cycles of $95^{\circ} \mathrm{C}$ for 1 minute, $55^{\circ} \mathrm{C}$ for 2 minutes, and $72^{\circ} \mathrm{C}$ for 1 minute, with a final phase of $72^{\circ} \mathrm{C}$ for 5 minutes. The MS ATCC 25204 and MG ATCC 129 S6 strains were used as positive controls and as ultrapure water negative control. For MS the reaction contained 1X PCR buffer (10mM Tris-HCl, pH 8.0 and $50 \mathrm{mM} \mathrm{KCl}) ; 1.5 \mathrm{mM} \mathrm{MgCl} 2 ; 0.2 \mathrm{mM}$ deoxyribonucleotide triphosphate (dNTP); $0.2 \mathrm{nmol}$ of each specific primer (Table 2); $1 \mathrm{U}$ Taq Polymerase, and extracted DNA, totaling $25 \mu \mathrm{l}$. MS PCR was performed under the following conditions: $94^{\circ} \mathrm{C}$ for 1 minute, followed by 40 cycles of $94^{\circ} \mathrm{C}$ for 30 seconds, $55^{\circ} \mathrm{C}$ for 30 seconds, and $72^{\circ} \mathrm{C}$ for 1 minute, with a final phase of $72^{\circ} \mathrm{C}$ for 5 minutes.

Electrophoresis. The amplicons obtained in PCR were applied in $1.5 \%$ agarose gel, submerged in Tris-Borato-EDTA Buffer (TBE), and then submitted to electrophoretic run at $94 \mathrm{~V}$ for 40 minutes. After the electrophoretic run, the gel was stained with ethidium bromide, and visualization of the amplicons was performed under ultraviolet light in a transilluminator.

Statistical analysis. Descriptive statistics were performed to obtain the percentages for Mycoplasma spp., MG, and MS for order taxonomic of birds. The Mann-Whitney non-parametric test was used to differentiate between the percentages obtained, which uses the median for comparative effects, with a significance level of $5 \%$ using the Bioestat $5.3{ }^{\circledR}$ software (Ayres et al. 2007).

\section{RESULTS AND DISCUSSION}

Of the 81 birds studied, none showed clinical respiratory signs at the time of collection. All birds were negative for isolation for Mycoplasma spp., while PCR for Mycoplasma spp. detected
$62.96 \%(51 / 81)$ of birds $1.96 \%(1 / 51)$ for $M G$ and $19.61 \%$ $(10 / 51)$ for MS, respectively representing $1.23 \%(1 / 81)$ and $12.34 \%(10 / 81)$ of the poultry total population studied (Table 3). In the statistical analysis by the Mann-Whitney test, the differences in percentages obtained between the orders about Mycoplasma spp. and MS, were significant $(\mathrm{p}<0.05)$, excluding the occurrence of MG because there was a single record during the study. Asymptomatic infections are the most common in mycoplasma-infected animals because these agents can escape of host immune system and remain dormant (Razin et al. 1998). Besides, the presence of low pathogenicity strains may cause a mild or inapparent clinical picture (Lecis et al. 2010).

The Falconiform and Cariamiform orders had only one individual tested in each of them, both being PCR positive for Mycoplasma spp., and the falconiform identified as MS positive. Without considering these specimens, the highest percentage of positive results for Mycoplasma spp. was observed in the Accipitriformes order, with $88.89 \%$ (16/18), 22.22\% (4/18) identified as positive for MS. Then, in Galliformes, $71.43 \%$ (5/7) of positive birds were found, with $14.29 \%$ (1/7) characterized with MS; Piciform, 60.00\% (3/5) for Mycoplasma spp. and 20.00\% (1/5) for MS; Psittaciformes, 53.33\% (24/45) for Mycoplasma spp., 2.22\% (1/45) for $M$. gallisepticum (MG) and 6.67\% (3/45) for MS. The order of lowest occurrence was Strigiformes with $25.00 \%$ (1/4) for Mycoplasma spp., but the species was not identified.

The results found for Psittaciformes contrast the studies of Silva et al. (2016) and Carvalho et al. (2017) when assessing the presence of Mycoplasma spp. in asymptomatic parrots under human care. Silva et al. (2016), when analyzing 85 parrots of different species from a zoo in Pernambuco, reported the presence of Mycoplasma spp. in $16.47 \%$ of the birds, however these mycoplasmas were not identified as MG or MS. Carvalho et al. (2017), when evaluating 300 samples of CETAS parrots, commercial and conservation breeding, observed positivity for M. gallisepticum (MG) in 21.6\% (16/74) in CETAS, $15.7 \%$ $(19 / 121)$ in commercial breeding, and $6.7 \%(7 / 105)$ in conservationist, while for MS the occurrences were $2.7 \%$ $(2 / 74)$ in CETAS, $0.0 \%(0 / 121)$ in commercial breeding and $1.9 \%(2 / 105)$ in conservationist. MG was still described with a high occurrence by Gomes et al. (2010) in parrots from the seizure of trafficking with the positivity of $85.4 \%$.

Table 3. Isolation and PCR detection of Mycoplasma spp., Mycoplasma gallisepticum and Mycoplasma synoviae by the order of the birds of Rio de Janeiro Zoo

\begin{tabular}{|c|c|c|c|c|}
\hline \multirow{2}{*}{ Order } & \multirow{2}{*}{$\begin{array}{c}\text { Isolation } \\
\text { Mspp.* }^{*}\end{array}$} & \multicolumn{3}{|c|}{ PCR } \\
\hline & & Mspp.* & $\mathrm{MG}^{* *}$ & MS*** \\
\hline Psittaciformes & $0 / 45(0 \%)$ & $24 / 45$ (53.33\%) & $1 / 45(2.22 \%)$ & $3 / 45(6.67 \%)$ \\
\hline Falconiformes & $0 / 1(0 \%)$ & $1 / 1(100.00 \%)$ & $0 / 1(0.00 \%)$ & $1 / 1(100.00 \%)$ \\
\hline Galliformes & $0 / 7(0 \%)$ & $5 / 7(71.43 \%)$ & $0 / 7(0.00 \%)$ & $1 / 7(14.29 \%)$ \\
\hline Strigiformes & $0 / 4(0 \%)$ & $1 / 4(25.00 \%)$ & $0 / 4(0.00 \%)$ & $0 / 4(0.00 \%)$ \\
\hline Cariamiformes & $0 / 1(0 \%)$ & $1 / 1(100.00 \%)$ & $0 / 1(0.00 \%)$ & $0 / 1(0.00 \%)$ \\
\hline TOTAL & $0 / 81(0 \%)$ & $51 / 81(62.96 \%)$ & 1/81 (1.23\%) & 10/81(12.3\%) \\
\hline
\end{tabular}

* Mspp.= Mycoplasma spp., ${ }^{* *} \mathrm{MG}=$ Mycoplasma gallisepticum, ${ }^{* * *} \mathrm{MS}=$ Mycoplasma synoviae. 
Lecis et al. (2016) analyzed samples of 62 birds of prey from two Wildlife Centers and a Veterinary Hospital in Italy, obtaining positivity for Mycoplasma spp. in 41.9\% (26/62) of them. In our study, we analyzed samples of three orders of birds considered of prey, Falconiformes, Accipitriformes, and Strigiformes in which we found positivities ranging from $25.00 \%$ to $88.89 \%$, that is, with a mean positivity of $56.95 \%$, with the prevalence obtained being higher than that presented by other authors. This difference may be due to the proximity between the nurseries, which may have favored or predisposed to mycoplasma infections (Kleven \& Fletcher 1983). Lecis et al. (2016) observed clinical symptoms compatible with mycoplasmosis in a positive individual; in the present study, such occurrence was not observed, despite the high frequency of mycoplasma positive birds. The high frequency found in asymptomatic prey corroborates other studies where a high frequency of mycoplasma was observed in birds of prey with mild or inapparent clinical presentation (Lierz et al. 2008, Lecis et al. 2010, Ziegler et al. 2019).

For Kleven (1998), there may be a preference for $M G$ and MS for Galliformes. However, in our study, the positivity for Mycoplasma spp. in this order was $71.43 \%$ (5/7), none positive for MG, and $14.29 \%(1 / 7)$ identified as MS in the wild Galliformes tested. Michiels et al. (2016) tested 15 wildlife Galliformes in Belgium, but none were positive; however, Haesendonck et al. (2014) demonstrated a high prevalence of $76.3 \%$ for MG and $36.0 \%$ for MS in Galliformes reared for ornamental purposes in the same country, suggesting that these birds may serve as a reservoir for these agents.

The high prevalence of Mycoplasma spp. in birds of the zoo, observed in this study, is important because birds with or in the subclinical state contribute to the maintenance of mycoplasmas in environments. Besides, its transmission occurs by diffusion in the form of aerosol or droplets, being the upper respiratory tract and conjunctiva the main entry doors of the pathogen (Nascimento \& Pereira 2009, Stipkovits \& Szathmary 2012). These agents are capable of causing respiratory signs, as well as severe reproductive disease in birds (Carnaccini et al. 2016), constituting a significant challenge for the conservation and rearing of wild and captive birds, because in addition to impairing rehabilitation, causes high mortality of embryos as well as young and adult birds (Gomes et al. 2010).

\section{CONCLUSIONS}

PCR was more effective than the isolation technique in detecting Mycoplasma spp. It was possible to detect mycoplasmas in birds of different orders without a clinical respiratory sign, obtaining Mycoplasma synoviae (MS) more prevalent than Mycoplasma gallisepticum (MG). The positivities for Mycoplasma spp., MG, and MS were different among the studied orders, being the highest occurrence in birds of prey, followed by Galliformes and Piciformes.

The presence of MG and MS in the birds of Rio Zoo confirms the circulation of these agents and the need for further studies on the dissemination of mycoplasmas in zoos for epidemiological analysis of these bacteria in this location.

Acknowledgements.- We thank the technical staff of the "Zoológico do Rio de Janeiro" (Rio de Janeiro Zoo) for the partnership to collect the biological material for the study. This study was supported by the "Coordenação de Aperfeiçoamento de Pessoal de Nível Superior” (CAPES), Brazil.

Conflict of interest statement. - The authors have no competing interests.

\section{REFERENCES}

Ayres M., Ayres Jr. M., Ayres D.L. \& Santos A.A.S. 2007. Bioestat 5.0 Aplicações Estatísticas nas Áreas das Ciências Biológicas e Médicas. 5th ed. Sociedade Civil Mamirauá, Belém. 364p.

Carnaccini S.N., Ferguson-Noel M.R., Chin P.T., Santoro P., Black M., Bland A., Bickford A. \& Sentíes-Cué C.G. 2016. A novel Mycoplasma sp. associated with phallus disease in goose breeders: pathological and bacteriological findings. Avian Dis. 60(2):437-443. <http://dx.doi.org/10.1637/11309102315-RegR>

Carvalho A.M., Andrade M.A., Linhares G.F. \& Jaime V.S. 2017. Pesquisa de Mycoplasma em aves da família Psittacidae mantidas em diferentes cativeiros no Brasil Central. Pesq. Vet. Bras. 37(10):1159-1164. <http:// dx.doi.org/10.1590/s0100-736x2017001000019>

Cubas Z.S. 2008. Biossegurança na manipulação de animais silvestres biossegurança em zoológicos. Ciênc. Vet. Tróp. 11(Supl.1):174-177.

Fischer J.R., Stallknecht D.E., Luttrell P., Dhondt A.A. \& Converse K.A. 1997. Mycoplasmal conjunctivitis in wild songbirds: the spread of a new contagious disease in a mobile host population. Emerg. Infect. Dis. 3(1):69-72. <http:// dx.doi.org/10.3201/eid0301.970110 > <PMid: 9126448>

Gomes A.M., Costa L.L., Vilela D.A.R., Marques M.V.R., Carvalhaes A.G., Marin S.Y., Costa M.P., Horta R.S., Resende J.S. \& Martins N.R.S. 2010. Detection of Mycoplasma gallisepticum in dead captive Psittacines in Belo Horizonte, Brazil. Revta Bras. Ciênc. Avic. 12(2):75-78. <http://dx.doi.org/10.1590/ S1516-635X2010000200001>

Haesendonck R., Verlinden M., Devos G., Michiels T., Butaye P., Haesebrouck F., Pasmans F. \& Martel A. 2014. High seroprevalence of respiratory pathogens in hobby poultry. Avian Dis. 58(4):623-627. <http://dx.doi. org/10.1637/10870-052314-ResNote.1><PMid:25619008>

Islam A., Aslam A., Chaudhry Z.I., Mansoor-Ud-Din A., Habib-Ur- Rehman L., Saeed K. \& Ahmed I. 2011. Pathology of Mycoplasma gallisepticum in naturally infected broilers and its diagnosis through PCR. Int. J. Agricult. Biol. 13(4):835-837.

Kleven S.H. \& Fletcher D.J. 1983. Laboratory infection of hause sparrows (Passer domesticus) with Mycoplasma gallisepticum and Mycoplasma synoviae. Avian Dis. 27(1):308-311. <PMid:6847547>

Kleven S.H. 1998. Mycoplasmas in the etiology of multifactorial respiratory disease. Poult. Sci. 77(8):1146-1149. <http://dx.doi.org/10.1093/ ps/77.8.1146><PMid:9706080>

Lauerman L.H., Hoerr F.J., Sharpton A.R., Shah S.M. \& Van Santen V.L. 1993. Development and Application of a Polymerase Chain Reaction Assay for Mycoplasma synoviae. Avian Dis. 37(3):829-834. <PMid:7504919>

Lecis R., Chessa B., Cacciotto C., Addis M.F., Coradduzza E., Berlinguer F., Muzzeddu M., Lierz M., Carcangiu L., Pittau M. \& Alberti A. 2010. Identification and characterization of novel Micoplasmas spp. belonging to the hominis group from griffon vultures. Res. Vet. Sci. 89(1):58-64. <http://dx.doi. org/10.1016/j.rvsc.2009.12.016>

Lecis R., Secci F., Mandas L., Muzzeddu M., Pittau M. \& Alberti A. 2016. Molecular Identification and Sequence Characterization of Mycoplasmas in Free-Living Birds of Prey. J. Zoo Wild Med. 47(3):917-922. <http:// dx.doi.org/10.1638/2015-0259.1><PMid:27691956>

Lewinsohn T.M. \& Prado P.I. 2005. Quantas espécies há no Brasil? Megadiversidade 1(1):36-42.

Lierz M., Hagen N., Hernadez-Divers S.J. \& Hafez H.M. 2008. Occurrence of Mycoplasmas In free-ranging birds of prey in Germany. J. Wildl. Dis. 44(4):845-850. <http://dx.doi.org/10.7589/0090-3558-44.4.845> $<$ PMid:18957640> 
Loria G.R., Ferrantelli E., Giardina G., Vecchi L.L., Sparacino L., Oliveri F., Mcauliffe L. \& Nicholas R.A.J. 2008. Isolation and characterization of unusual Mycoplasma spp. from captive Eurasian griffon (Gys fulvus) in Sicily. J. Wildlife Dis. 44(1):159-163. <http://dx.doi.org/10.7589/00903558-44.1.159><PMid:18263832>

Michiels T., Welby S., Vanrobaeys M., Quinet C., Rouffaer L., Lens L., Martel A. \& Butaye P. 2016. Prevalence of Mycoplasma gallisepticum and Mycoplasma synoviae in commercial poultry, racing pigeons and wild birds in Belgium. Avian Pathol. 45(2):244-252. <http://dx.doi.org/10.1080/03079457.20 16.1145354><PMid:26814376>

Nascimento E.R. \& Pereira V.L.A. 2009. Micoplasmoses, p.485-495. In: Berchieri Jr A., Silva E.N., Di Fábio J., Sesti L. \& Zuanaze M.A.F. (Eds), Doenças das Aves. $2^{2}$ ed. Ed. Facta, Fundação de APINCO de Ciência e Tecnologia Avícolas, Campinas, SP.

Nascimento E.R. 2000. Micoplasmoses, p.217-240. In: Macari M. \& Berchieri Jr A. (Eds.), Doenças das Aves. FACTA, Campinas, SP.

Nascimento E.R., Pereira V.L.A., Nascimento M.G.F. \& Barreto M.L. 2005. Avian mycoplasmosis update. Revta Bras. Ciênc. Avíc. 7(1):1-9. <http://dx.doi. org/10.1590/S1516-635X2005000100001>

Oaks J.L., Donahoe S.L., Rurangirwa F.R., Rideout B.A., Gilbert M. \& Virani M.Z. 2004. Identification of a novel Mycoplasma species from an oriental white backed vulture (Gyps bengalensis). J. Clin. Microbiol. 42(12):5909-5912. <http://dx.doi.org/10.1128/JCM.42.12.5909-5912.2004><PMid:15583338>

Panangala V.S., Stringfellow J.S., Dybvig K., Woodard A., Sun F., Rose L. \& Gresham M.M. 1993. Mycoplasma corogypsi sp. nov., a new species from the footpad abscess of a black vulture, Coragyps atratus. Int. J. Syst. Bacteriol. 43(3):585-590. <http://dx.doi.org/10.1099/00207713-43-3585><PMid:8347515>

Phalen D.N., Logan K.S. \& Snowden K.F. 2006. Encephalitozoon bellem infection as the cause of a unilateral chronic keratoconjunctivitis in an umbrella cockatoo (Cacatua alba). Vet. Ophthalmol. 9(1):59-63. <http://dx.doi. org/10.1111/j.1463-5224.2005.00434.x> <PMid:16409247>

Poveda J.B., Carranza J., Miranda A., Garrido A., Hermoso M., Fernandez A. \& Domenech J. 1990. An epizootiological study of avian mycoplasmas in Southern Spain. Avian Pathol. 19:627-633. <http://dx.doi. org/10.1080/03079459008418718>
Razin S., Yogev D., Naot Y. 1998. Molecular biology and pathogenicity of mycoplasmas. Microbiol. Mol. Biol. Rev. 62(4):1094-156. <PMid: 9841667>

Sambrook J. \& Russell D.W. 2006. Purification of nucleic acids by extraction with phenol-chloroform. CSH Protoc. 2006(1).<http://dx.doi.org/10.1101/ pdb.prot4455><PMid:22485786>

Silva L.T.R., Santos S.B., Rameh-de-Albuquerque L.C., Siqueir D.B., Amorim M.M.R., Almeida J. \& Mota R.A. 2016. Detecção molecular e isolamento de Mycoplasma spp. em psitacídeos no estado de Pernambuco, Brasil. Arq. Bras. Med. Vet. Zootec. 68(1):113-118. <http://dx.doi.org/10.1590/16784162-8387>

Stipkovits L. \& Kempft I. 1996. Mycoplasmosis in poultry. Rev. Sci. Tech. Off. Int. Épiz. 15(4):1495-1525. <http://dx.doi.org/10.20506/rst.15.4.986> $<$ PMid:9190023>

Stipkovits L. \& Szathmary S. 2012. Mycoplasma infection of ducks and geese. Poult Sci. 91(11): 2812-2819. <http://dx.doi.org/10.3382/ps.2012-02310> <PMid: 23091137>

Umar S., Munir M.T., Ur-Rehman Z., Subhan S., Azam T. \& Shah M.A.A. 2017. Mycoplasmosis in poultry: update on diagnosis and preventive measures. Worlds Poult. Sci. J. 73(1):17-28. <http://dx.doi.org/10.1017/ S0043933916000830>

Van Kuppeveld F.J., Van der Logt J.T., Angulo A.F., Van Zoest M.J., Quin W.G., Niesters H.G. \& Melchers W.J. 1992. Genus-and species-specific identification of mycoplasmas by $16 \mathrm{~S}$ rRNA amplification. Appl. Environ. Microbiol. 58(8): 2606-2615. <PMid:1381174>

Van Kuppeveld F.J., Van der Logt J.T., Angulo A.F., Van Zoest M.J., Quint W.G., Niesters H.G. \& Melchers W.J. 1993. Genus-and species-specific identification of mycoplasmas by $16 \mathrm{~S}$ rRNA amplification. Appl. Environ. Microbiol. 59(2):655.<http://dx.doi.org/10.1128/AEM.59.2.655-.1993> $<$ PMid:8434934>

Vilani R.G.D.C. 2006. Estrutura hospitalar, quarentenário e centros de triagem, p.33-42. In: Cubas Z.S., Silva J.C.R. \& Catão-Dias J.L. (Eds), Tratado de Animais Selvagens: medicina veterinária. Roca, São Paulo, SP.

Ziegler L., Palau-Ribes F.M., Enderlein D., Herbst W., Schmidt L. \& Lierz M. 2019. Mycoplasma hafezii sp. nov., isolated from the trachea of a peregrine falcon (Falco peregrinus). Int. J. Syst. Evol. Microbiol. 69(3):773-777. <http:// dx.doi.org/10.1099/ijsem.0.003235><PMid:30707094> 